\title{
Proteiniphilum acetatigenes gen. nov., sp. nov., from a UASB reactor treating brewery wastewater
}

Correspondence

Xiuzhu Dong

dongxz@sun.im.ac.cn
In methanogenic environments, propionate, one of the central intermediates in the degradation of complex organic matter to $\mathrm{CO}_{2}$ and methane, can be converted to methane and acetate only by the concerted action of syntrophic bacteria and methanogens, because of energetics difficulties (Schink, 1997). Neither syntrophic propionate-degrading bacteria nor methanogens utilize saccharides and proteinaceous substances, but can utilize short-chain organic acids or inorganics such as $\mathrm{CO}_{2}$. Pyruvate is an important intermediate not only in the syntrophic degradation of propionate, but also in the dissimilation of glucose and some amino acids. During an investigation of syntrophic

Published online ahead of print on 3 June 2005 as DOI 10.1099/ ijs.0.63807-0.

Abbreviations: CFB, Cytophaga-Flavobacterium-Bacteroides; UASB, upflow anaerobic sludge blanket.

The GenBank/EMBL/DDBJ accession number for the $16 \mathrm{~S}$ rRNA gene sequence of Proteiniphilum acetatigenes TB107 ${ }^{\top}$ is AY742226.

A comparison of the cellular fatty acid compositions of Proteiniphilum acetatigenes TB107 ${ }^{\mathrm{T}}$ and its phylogenetic relatives is available as a supplementary table in IJSEM Online. propionate-degrading bacteria from methanogenic environments, some propionate-degrading tricultures were isolated. These tricultures degraded propionate to acetate and methane, and included three different micro-organisms; firstly, an egg-shaped, syntrophic, propionate-degrading bacterium (Chen et al., 2005); secondly, Methanobacterium formicicum-like cells; and finally, an unidentified rodshaped bacterium. The rod-shaped bacterium on its own did not consume propionate or synthesize methane; however, it accelerated the propionate-degradation rate of the triculture. The purified rod-shaped bacterial strains utilized pyruvate and produced acetate and propionate from proteinaceous materials, but not glucose or other sugars. Phylogenetically the strains were affiliated to the CytophagaFlavobacterium-Bacteroides (CFB) group; however, they were only distantly related to recognized genera in this cluster. Hence, a new genus was designated based on the distinctive phenotypic and phylogenetic characteristics of the two strains.

Strains $\mathrm{TB}_{107^{\mathrm{T}}}$ and TB6-6 were isolated in pre-reduced peptone-yeast extract (PY) medium (Holdeman et al., 1977) 
from methanogenic propionate-degrading mixtures by serial dilution and the Hungate roll-tube technique (Hungate, 1969). Single colonies were picked, and transferred to the same broth and incubated at $37^{\circ} \mathrm{C}$ for 2 days. The roll-tube procedure was repeated several times until a pure culture was obtained. Culture purity was also checked by microscopic examination. Routine cultivation was in PY broth in anaerobic tubes $(18 \times 180 \mathrm{~mm})$ sealed with butyl rubber stoppers under a gaseous atmosphere of $100 \% \mathrm{~N}_{2}$ $(100 \mathrm{kPa})$ at $37^{\circ} \mathrm{C}$.

Substrate utilization studies were performed in a basal medium containing various substrates: peptone, yeast extract and tryptone at $0.2 \%$ (final concentration); sugars, fatty acids and alcohols at $20 \mathrm{mM}$ (final concentration); and amino acids at $10 \mathrm{mM}$ (final concentration). The basal medium contained $\left(1^{-1}\right): 1 \mathrm{~g} \mathrm{NH}_{4} \mathrm{Cl}, 0 \cdot 3 \mathrm{~g} \mathrm{~K}_{2} \mathrm{HPO}_{4}$, $0 \cdot 3 \mathrm{~g} \mathrm{KH}_{2} \mathrm{PO}_{4}, 0.6 \mathrm{~g} \mathrm{NaCl}, 0 \cdot 1 \mathrm{~g} \mathrm{CaCl}_{2} .2 \mathrm{H}_{2} \mathrm{O}, 0 \cdot 2 \mathrm{~g} \mathrm{MgCl}_{2}$, $0 \cdot 1 \mathrm{~g} \mathrm{KCl}$ and $1 \mathrm{mg}$ resazurin. The $\mathrm{pH}$ was adjusted to 7 with $1 \mathrm{M} \mathrm{NaOH}$ and cultivation conditions were as described above.

Cell morphology was examined under a light microscope (Olympus BH-2) and an electron microscope (Hitachi H-600A). For electron microscopy studies, bacterial cells grown in $\mathrm{PY}$ at $37^{\circ} \mathrm{C}$ for 2 days were negatively stained with uranyl acetate. For ultrathin-section examination of the cell wall, bacterial cells were fixed with osmic acid and embedded in araldite; the samples were then sliced and stained with lead citrate (Reynolds, 1963).

The generation time of the strains was determined by monitoring the $\mathrm{OD}_{600}$ of the PY culture at $37^{\circ} \mathrm{C}$ at $1 \mathrm{~h}$ intervals up to $72 \mathrm{~h}$. Temperature profiles were determined in PY broth by using a water bath (Guangming medical instrument plant, Beijing) at temperatures of 15 to $55^{\circ} \mathrm{C}$, at $1{ }^{\circ} \mathrm{C}$ intervals. The $\mathrm{pH}$ range for growth was determined in $\mathrm{PY}$ broth at various $\mathrm{pH}$ values adjusted with $\mathrm{HCl}$ or $\mathrm{NaOH}$ $\left(1 \mathrm{~mol} \mathrm{l}^{-1}\right)$. Growth was determined by measuring the $\mathrm{OD}_{600}$ of cultures at 1, 3 and 7 days. Biochemical traits were determined using both conventional methods (Holdeman et al., 1977) and the API $50 \mathrm{CH}$ system (bioMérieux). All of the tests were performed in duplicate. Short-chain fatty acids and gases of fermentation were detected by using a gas chromatograph (GC-14B; Shimadzu), as described previously (Chen \& Dong, 2004).

Genomic DNA was extracted and purified by using the method of Marmur (1961). The G+C content of the DNA was determined by the thermal denaturation method (Marmur \& Doty, 1962) using a DU800 spectrophotometer (Beckman) with Escherichia coli $\mathrm{K}-12$ as the reference. The $16 \mathrm{~S}$ rRNA gene was amplified and sequenced according to Chen \& Dong (2004). Sequencing was performed by Sangon Biological Engineering Technology Service, Shanghai, China, using ABI PRISM Big Dye Terminator cycle sequencing ready reaction kits (Perkin Elmer) and an $\mathrm{ABI}$ PRISM 377XL DNA sequencer. The 16S rRNA gene sequence of strain $\mathrm{TB} 107^{\mathrm{T}}$ was submitted to GenBank and
EMBL to search for similar sequences using the BLAST algorithm. The best matching sequences were retrieved from the database and aligned, and similarity analysis was performed using the program CLUSTAL_X (Thompson et al., 1997). Phylogenetic trees were constructed by using neighbour-joining, maximum-likelihood and maximumparsimony methods implemented in the program MEGA2 (Kumar et al., 2001) and the PHYLIP package (Felsenstein, 1993). The resultant tree topologies were evaluated by bootstrap analysis (Felsenstein, 1985) based on 1000 resamplings.

Cellular fatty acids were extracted, methylated and analysed using the standard MIDI (Microbial Identification) system (Miller, 1982; Sasser, 1990).

Cells of strains $\mathrm{TB} 107^{\mathrm{T}}$ and TB6-6 were rod-shaped $(0.6-0.9 \times 1 \cdot 9-2 \cdot 2 \mu \mathrm{m})$, occurring singly or in pairs, and were motile by means of two peritrichous flagella (Fig. 1a). The cell wall was Gram-negative, as confirmed by the $\mathrm{KOH}$ lysis test (Smibert \& Krieg, 1994) and ultrathin-section electron microscopy of strain $\mathrm{TB}_{107^{\mathrm{T}}}$ (Fig. 1b). No spores were observed and resistance to treatment at $80^{\circ} \mathrm{C}$ for 10 min was not observed. Colonies on PY agar were white, smooth, circular, entire, translucent and slightly convex, reaching $1.5 \mathrm{~mm}$ in diameter after cultivation at $37^{\circ} \mathrm{C}$ for $72 \mathrm{~h}$.

Strains TB $107^{\mathrm{T}}$ and TB6-6 grew exclusively in pre-reduced media and growth was completely inhibited by air. Both strains grew at $20-45^{\circ} \mathrm{C}$ and $\mathrm{pH} 6 \cdot 0-9 \cdot 7$, with optimum growth occurring at $37^{\circ} \mathrm{C}$ and approximately $\mathrm{pH} 7 \cdot 5-8 \cdot 0$. The two strains could grow in the presence of $0-5 \%(\mathrm{w} / \mathrm{v})$ $\mathrm{NaCl}$. The mean generation time of strain $\mathrm{TB} 107^{\mathrm{T}}$ was $11.2 \mathrm{~h}$ when grown in $\mathrm{PY}$ at $37^{\circ} \mathrm{C}$. The strains were proteolytic. Yeast extract, peptone, pyruvate, glycine and L-arginine could be used as carbon and energy sources. Weak growth was also observed with tryptone, L-serine, L-threonine and L-alanine. The two strains did not use any of the tested carbohydrates, alcohols and fatty acids except pyruvate (detailed data are given in the species description) and did not grow in medium containing $20 \%$ bile. Acetic acid $(18 \mathrm{mM})$ and propionate $(10 \mathrm{mM})$ were produced from $1 \%$ yeast extract, and $10 \mathrm{mM}$ acetic acid and trace amounts of propionate were also produced from $0.5 \%$ peptone. Pyruvate was converted to acetic acid and $\mathrm{CO}_{2}$. In addition to acetic acid and propionic acid, a trace amount of succinic acid was occasionally detected in PY medium.

The two strains exhibited almost identical physiological and biochemical profiles determined using conventional methods as well as the API $50 \mathrm{CH}$ system. Both isolates hydrolysed aesculin and starch, but not gelatin. $\mathrm{NH}_{3}$ was produced from yeast extract, peptone and L-arginine, but indole was not produced. $\mathrm{H}_{2} \mathrm{~S}$ was not produced from peptone or thiosulfate.

The similarity between the partial 16S rRNA gene sequences (500 bp) of strains TB107 ${ }^{\mathrm{T}}$ and TB6-6 was $99 \cdot 6 \%$ and their 

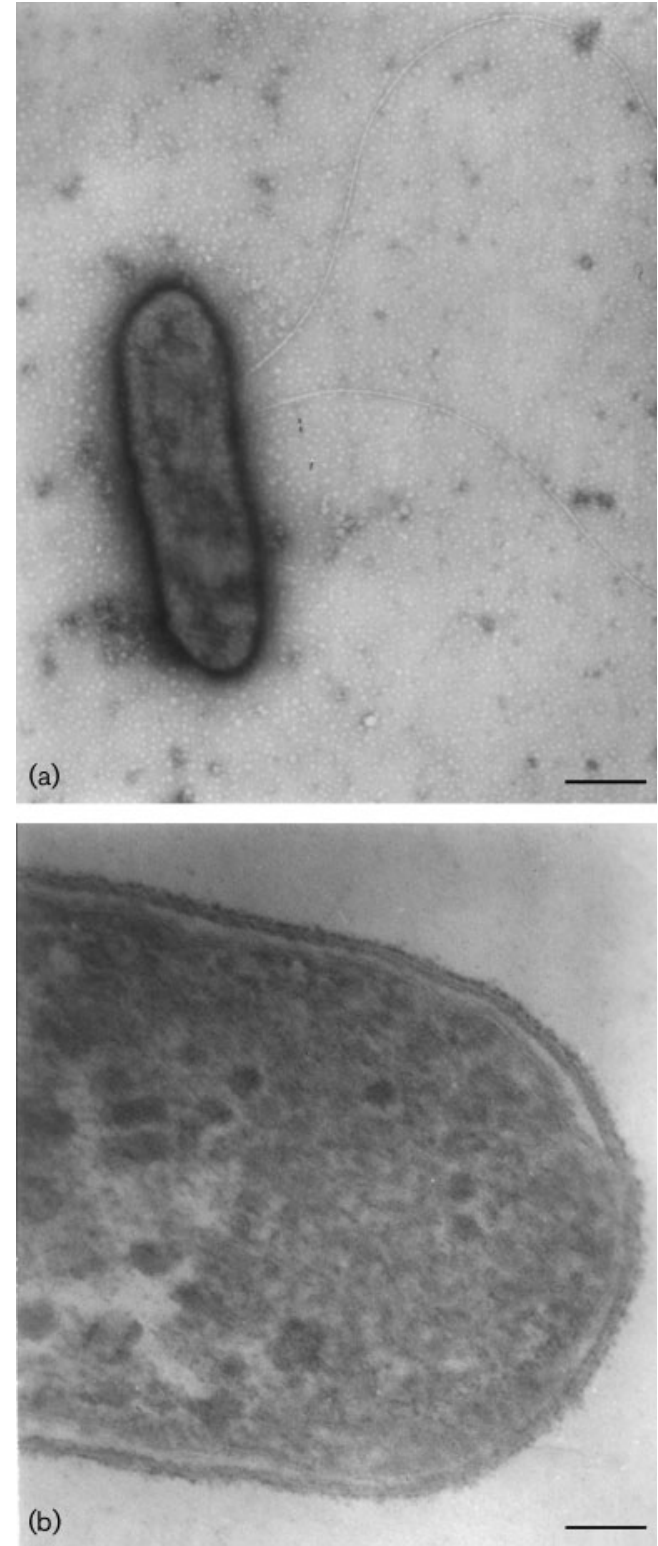

Fig. 1. Transmission electron micrographs of a cell of strain $\mathrm{TB} 107^{\top}$ (a) and an ultrathin section (b). Bars, $0.5 \mu \mathrm{m}$ (a) and $0 \cdot 1 \mu \mathrm{m}(b)$.

$\mathrm{G}+\mathrm{C}$ contents were $46 \cdot 6$ and $48 \cdot 9 \mathrm{~mol} \%$, respectively. All of the above results indicate the single species status of the two isolates.

To ascertain the phylogenetic position of the new isolates, the complete $16 \mathrm{~S}$ rRNA gene sequence $(1523 \mathrm{bp})$ of strain $\mathrm{TB} 107^{\mathrm{T}}$ was compared with the most similar sequences retrieved from GenBank. On the basis of a consensus 1424 bp of the $16 \mathrm{~S}$ rRNA gene sequence, a phylogenetic tree rooted with Capnocytophaga gingivalis ATCC $33624^{\mathrm{T}}$ and Capnocytophaga haemolytica JCM $8565^{\mathrm{T}}$ was constructed (Fig. 2). Phylogenetic analysis showed that strain TB107 ${ }^{\mathrm{T}}$ belonged to the CFB group (Paster et al., 1994) and clustered with Dysgonomonas species (89·6-90.6\% sequence similarity). Bootstrap resampling showed that this relationship was statistically significant ( $97 \%$ recovery in 1000 resamplings). Other remotely related taxa included the genera Bacteroides (85-87\% sequence similarity), Porphyromonas (84-88\% sequence similarity), Prevotella (79-85\% sequence similarity) and Tannerella forsythensis ( $89 \cdot 3 \%$ sequence similarity). Based on the sequence divergence, it was evident that the new isolates could not be assigned to any of the described genera in this cluster.

Strains TB107 ${ }^{\mathrm{T}}$ and TB6-6 also showed distinct phenotypic features that distinguished them from representative members in the same cluster (Table 1). They differed from Dysgonomonas species by the latter's cell shape of coccobacilli, facultative anaerobic growth, lower genomic DNA $\mathrm{G}+\mathrm{C}$ content (38 mol\%) and the ability to ferment glucose. Unlike the non-motile fusiform species $T$. forsythensis, the new isolates did not produce phenylacetic acid and butyric acid from glucose. The novel species differed from Bacteroides distasonis and Bacteroides merdae by the latter being non-motile and able to produce a large amount of succinic acid during glucose fermentation.

The cellular fatty acids of strain $\mathrm{TB} 107^{\mathrm{T}}$ were characterized mainly by iso-branched fatty acids, predominantly anteiso- $\mathrm{C}_{15: 0}(46 \cdot 21 \%) . \mathrm{C}_{15: 0}(8 \cdot 90 \%)$, iso- $\mathrm{C}_{17: 0} 3-\mathrm{OH}$ $(5 \cdot 93 \%)$ and anteiso- $\mathrm{C}_{17: 0}(5 \cdot 15 \%)$ fatty acids were also relatively abundant, and were proportionally different to those of phylogenetically related genera and species (see the supplementary table in IJSEM Online). Previous studies revealed that iso- $\mathrm{C}_{15: 0}$ accounted for $33-58 \%$ of the fatty acids of Porphyromonas strains, and that anteiso$\mathrm{C}_{15: 0}$, iso- $\mathrm{C}_{15: 0}$, iso- $\mathrm{C}_{17: 0}$ and $\mathrm{C}_{16: 0}$ were the major cellular fatty acids of Bacteroides and Prevotella (Moore et al., 1994).

An obligate syntrophic propionate-degrading bacterium, Syntrophobacter sulfatireducens DSM $16706^{\mathrm{T}}$, was also isolated from the same upflow anaerobic sludge blanket (UASB) reactor as strain $\mathrm{TB} 107^{\mathrm{T}}$ (Chen et al., 2005). This syntrophic strain converted $20 \mathrm{mM}$ propionate to acetate and methane in co-culture with $M$. formicicum DSM $1535^{\mathrm{T}}$ in 50-60 days, with a propionate-degradation rate of $0.75 \mathrm{mM}$ per day during the exponential phase. When in the triculture with strain $\mathrm{TB} 107^{\mathrm{T}}, 20 \mathrm{mM}$ propionate could be degraded in less than 30 days and the degradation rate was accelerated to about $1.25 \mathrm{mM}$ per day. It appeared that acceleration of the propionate-degradation rate of the syntrophic propionate co-culture by strain $\mathrm{TB} 107^{\mathrm{T}}$ was due to the provision of unknown nutrient factors or the depletion of pyruvate.

\section{Description of Proteiniphilum gen. nov.}

Proteiniphilum (Pro.tei'ni.phi.lum. N.L. neut. n. proteinum protein; Gr. adj. philos loving; N.L. neut. n. Proteiniphilum protein loving). 


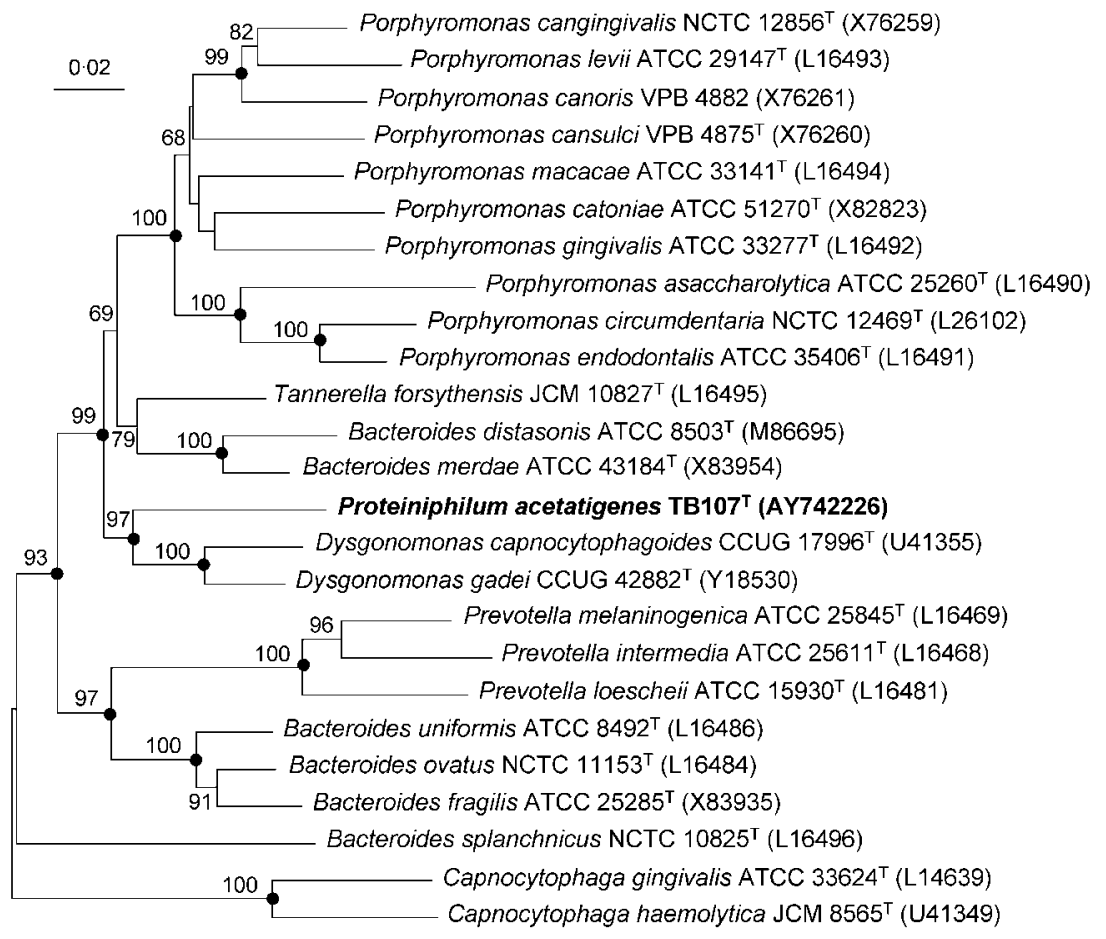

Fig. 2. Phylogenetic dendrogram of Proteiniphilum acetatigenes $\mathrm{TB}^{\mathrm{T}} 107^{\top}$ and related species based on 16S rRNA gene sequence similarity. The tree was rooted with C. gingivalis ATCC $33624^{\top}$ and C. haemolytica $\mathrm{JCM} 8565^{\top}$, and was constructed using the neighbour-joining method. Solid circles indicate that the corresponding nodes (groups) were also recovered using maximum-likelihood and maximum-parsimony methods. Numbers at nodes represent percentage levels of bootstrap support based on a neighbour-joining analysis of 1000 resampled datasets. GenBank accession numbers of $16 \mathrm{~S}$ rRNA gene sequences are given in parentheses. Bar, $2 \%$ sequence divergence.

Gram-negative, motile, non-spore-forming rods. Obligately anaerobic. Microaerophilic or aerobic growth does not occur. Cellular fatty acids mainly consist of iso-branched fatty acids, predominantly anteiso- $\mathrm{C}_{15: 0}$. Mesophilic. Grow at $20-45^{\circ} \mathrm{C}$. Chemoorganotrophic. Cytochrome oxidase and catalase are not produced. Proteolytic. Yeast extract and peptone can be used as energy sources. Carbohydrates and alcohols are not used. Gelatin is not hydrolysed. Not resistant to $20 \%$ bile. The major fermentation products from PY are acetic acid and propionic acid. Nitrate is not reduced. The $\mathrm{G}+\mathrm{C}$ contents of the genomic DNA of the known strains of the type species are 46.6 and $48.9 \mathrm{~mol} \%$. Only one species, Proteiniphilum acetatigenes, is described so far; this species has been designated the type species.

Table 1. Characteristics that can be used to differentiate Proteiniphilum acetatigenes sp. nov. TB10 $7^{\top}$ from its phylogenetic relatives

Species: 1, Proteiniphilum acetatigenes TB107 ${ }^{\mathrm{T}} ; 2$, Dysgonomonas capnocytophagoides CCUG $17996^{\mathrm{T}}$ (Hofstad et al., 2000); 3, Dysgonomonas

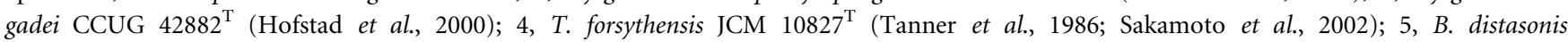
ATCC $8503^{\mathrm{T}}$ (Holdeman et al., 1984); 6, B. merdae ATCC $43184^{\mathrm{T}}$ (Johnson et al., 1986). Symbols: +, positive; -, negative.

\begin{tabular}{|c|c|c|c|c|c|c|}
\hline Characteristic & 1 & 2 & 3 & 4 & 5 & 6 \\
\hline Inhabiting niche & UASB sludge & Clinical specimen & Infected gall bladder & Periodontal pockets & Faeces & Faeces \\
\hline Cell shape & Rod & $\begin{array}{c}\text { Coccobacilli to } \\
\text { short rod }\end{array}$ & Coccobacilli & Fusiform & Rod & Rod \\
\hline Motile & + & - & - & - & - & - \\
\hline Relation to $\mathrm{O}_{2}$ & $\begin{array}{l}\text { Obligate } \\
\text { anaerobe }\end{array}$ & $\begin{array}{l}\text { Facultative } \\
\text { anaerobe }\end{array}$ & $\begin{array}{l}\text { Facultative } \\
\text { anaerobe }\end{array}$ & $\begin{array}{l}\text { Obligate } \\
\text { anaerobe }\end{array}$ & $\begin{array}{l}\text { Obligate } \\
\text { anaerobe }\end{array}$ & $\begin{array}{l}\text { Obligate } \\
\text { anaerobe }\end{array}$ \\
\hline $\begin{array}{l}\text { DNA G }+ \text { C content } \\
(\mathrm{mol} \%)\end{array}$ & $46 \cdot 6$ & 38 & 38 & 46 & $43-45$ & 44 \\
\hline Glucose fermentation & - & + & + & - & + & + \\
\hline $\begin{array}{l}\text { Major products from } \\
\text { PY or } \mathrm{PYG}^{*}\end{array}$ & $\mathrm{AP}(\mathrm{s})$ & PLS & {$[+]$} & ABiVPPa & SAp(ivibl) & SApibiv \\
\hline Resistant to ox bile & - & + & + & - & + & + \\
\hline
\end{tabular}

*Products from PY or peptone-yeast extract-glucose (PYG) medium: upper-case letters, >1 meq of acid per $100 \mathrm{ml}$ broth; lower-case letters, $<1$ meq of acid per $100 \mathrm{ml}$; A, acetic acid; B, butyric acid; L, lactic acid; P, propionic acid; S, succinic acid; iB, isobutyric acid; iV, isovaleric acid; $\mathrm{Pa}$, phenylacetic acid; [+], acid is produced. Products in parentheses may or may not be detected. 


\section{Description of Proteiniphilum acetatigenes sp. nov.}

Proteiniphilum acetatigenes (a.ce'ta.ti.gen.es. N.L. acetas -atis acetate; Gr. v. gennao produce; N.L. part. adj. acetatigenes acetate-producing).

Morphology and general characteristics are as described for the genus. Cells are $0 \cdot 6-0 \cdot 9 \times 1 \cdot 9-2 \cdot 2 \mu \mathrm{m}$. Colonies on PY agar are circular, slightly convex, white, translucent, and reach $1.5 \mathrm{~mm}$ in diameter after 3 days incubation at $37^{\circ} \mathrm{C}$. Optimum growth occurs at $37^{\circ} \mathrm{C}$. The $\mathrm{pH}$ range for growth is $6 \cdot 0-9 \cdot 7$, with optimum growth occurring at $\mathrm{pH} 7 \cdot 5-8 \cdot 0$. In addition to yeast extract and peptone, pyruvate, glycine and L-arginine can be used as carbon and energy sources. Weak growth is observed with tryptone, L-serine, Lthreonine and L-alanine. Acetic acid is the main product from fermentation of yeast extract, peptone, pyruvate and $\mathrm{L}$-arginine. Propionic acid is also produced from yeast extract. The following substrates are not used: L-histidine, Lleucine, L-lysine, L-methionine, L-phenylalanine, L-valine, L-glutamine, tryptophan, L-tyrosine, L-isoleucine, L-proline, L-aspartate, L-cysteine, L-arabinose, cellobiose, aesculin, Dfructose, D-galactose, D-glucose, glycogen, inulin, D-lactose, D-maltose, mannose, melibiose, raffinose, rhamnose, ribose, sucrose, salicin, sorbose, starch, trehalose, D-xylose, adonitol, amygdalin, dulcitol, erythritol, inositol, mannitol, sorbitol, ribitol, methanol, ethanol, 1-propanol, citrate, fumarate, malate, succinate, malonate, hippurate, sodium gluconate, butane diacid, $\beta$-hydroxybutyric acid, phenylacetic acid, cellulose and xylan. Milk is not curdled. Starch and aesculin are hydrolysed. Indole is not produced. Urease, lecithinase and lipase are not produced. Methyl red and Voges-Proskauer tests are negative. $\mathrm{H}_{2} \mathrm{~S}$ is not produced from peptone or thiosulfate. $\mathrm{NH}_{3}$ is produced from yeast extract, peptone and L-arginine. The major cellular fatty acids are anteiso- $\mathrm{C}_{15: 0}(46 \cdot 21 \%), \mathrm{C}_{15: 0}(8 \cdot 90 \%)$, iso- $\mathrm{C}_{17: 0}$ $3-\mathrm{OH}(5 \cdot 93 \%)$ and anteiso- $\mathrm{C}_{17: 0}(5 \cdot 15 \%)$.

The type strain is $\mathrm{TB} 107^{\mathrm{T}}\left(=\mathrm{JCM} 12891^{\mathrm{T}}=\right.$ AS $\left.1.5024^{\mathrm{T}}\right)$, which was isolated from the granule sludge of a UASB reactor treating brewery wastewater.

\section{Acknowledgements}

This study was supported by the National Basic Research Program of China (2004CB719602) and the innovation program (field frontier) from the Chinese Academy of Sciences and '863' Program (2004AA227100).

\section{References}

Chen, S. \& Dong, X. (2004). Acetanaerobacterium elongatum gen. nov., sp. nov., from paper mill waste water. Int J Syst Evol Microbiol 54, 2257-2262.

Chen, S., Liu, X. \& Dong, X. (2005). Syntrophobacter sulfatireducens sp. nov., a novel syntrophic, propionate-oxidizing bacterium isolated from UASB reactors. Int J Syst Evol Microbiol 55, 1319-1324.

Felsenstein, J. (1985). Confidence limits on phylogenies: an approach using the bootstrap. Evolution 39, 783-791.
Felsenstein, J. (1993). PHYLIP (phylogeny inference package), version 3.5c. Department of Genome Sciences, University of Washington, Seattle, USA.

Hofstad, T., Olsen, I., Eribe, E. R., Falsen, E., Collins, M. D. \& Lawson, P. A. (2000). Dysgonomonas gen. nov. to accommodate Dysgonomonas gadei sp. nov., an organism isolated from a human gall bladder, and Dysgonomonas capnocytophagoides (formerly CDC group DF-3). Int J Syst Evol Microbiol 50, 2189-2195.

Holdeman, L. V., Cato, E. P. \& Moore, W. E. C. (1977). Anaerobe Laboratory Manual, 4th edn. Blacksburg, VA: Virginia Polytechnic Institute and State University.

Holdeman, L. V., Kelley, R. W. \& Moore, W. E. C. (1984). Genus I. Bacteroides Castellani and Chalmers 1919, 959 ${ }^{\mathrm{AL}}$. In Bergey's Manual of Systematic Bacteriology, vol. 1, pp. 604-631. Edited by N. R. Krieg \& J. G. Holt. Baltimore: Williams \& Wilkins.

Hungate, R. E. (1969). A roll tube method for cultivation of strict anaerobes. Methods Microbiol 3B, 117-132.

Johnson, J. L., Moore, W. E. C. \& Moore, L. V. H. (1986). Bacteroides caccae sp. nov., Bacteroides merdae sp. nov., and Bacteroides stercoris sp. nov. isolated from human feces. Int J Syst Bacteriol 36, 499-501.

Kumar, S., Tamura, K., Jakobsen, I. B. \& Nei, M. (2001). MEGA2: molecular evolutionary genetics analysis software. Bioinformatics 17, 1244-1245.

Marmur, J. (1961). A procedure for the isolation of deoxyribonucleic acid from microorganisms. J Mol Biol 3, 208-218.

Marmur, J. \& Doty, P. (1962). Determination of the base composition of deoxyribonucleic acid from its thermal denaturation temperature. J Mol Biol 5, 109-118.

Miller, L. T. (1982). Single derivatization method for routine analysis of bacterial whole-cell fatty acid methyl esters, including hydroxy acids. J Clin Microbiol 16, 584-586.

Moore, L. V. H., Bourne, D. M. \& Moore, W. E. C. (1994). Comparative distribution and taxonomic value of cellular fatty acids in thirty-three genera of anaerobic Gram-negative bacilli. Int J Syst Bacteriol 44, 338-347.

Paster, B. J., Dewhirst, F. E., Olsen, I. \& Fraser, G. J. (1994). Phylogeny of Bacteroides, Prevotella, and Porphyromonas spp. and related bacteria. J Bacteriol 176, 725-732.

Reynolds, E. S. (1963). The use of lead citrate at high $\mathrm{pH}$ as an electron-opaque stain in electron microscopy. J Cell Biol 17, 208-212.

Sakamoto, M., Suzuki, M., Umeda, M., Ishikawa, I. \& Benno, Y. (2002). Reclassification of Bacteroides forsythus (Tanner et al. 1986) as Tannerella forsythensis corrig., gen. nov., comb. nov. Int J Syst Evol Microbiol 52, 841-849.

Sasser, M. (1990). Identification of bacteria by gas chromatography of cellular fatty acids. Technical Note 101. Newark, DE: MIDI.

Schink, B. (1997). Energetics of syntrophic cooperation in methanogenic degradation. Microbiol Mol Biol Rev 61, 262-280.

Smibert, R. M. \& Krieg, N. R. (1994). Phenotypic characterization. In Methods for General and Molecular Bacteriology, pp. 607-654. Edited by P. Gerhardt, R. G. E. Murray, W. A. Woods \& N. R. Krieg. Washington, DC: American Society for Microbiology.

Tanner, A. C. R., Listgarten, M. A., Ebersole, J. L. \& Strzempko, M. N. (1986). Bacteroides forsythus sp. nov., a slow-growing, fusiform Bacteroides sp. from the human oral cavity. Int J Syst Bacteriol 36, 213-221.

Thompson, J. D., Gibson, T. J., Plewniak, F., Jeanmougin, F. \& Higgins, D. G. (1997). The CLUSTAL_X Windows interface: flexible strategies for multiple sequence alignment aided by quality analysis tools. Nucleic Acids Res 25, 4876-4882. 